\title{
Is Trade in COVID-19 Products in ASEAN Economies a Building or Stumbling Block?
}

\author{
Nathapornpan Piyaareekul Uttama ${ }^{1+}$ \\ ${ }^{1}$ Mae Fah Luang University, Thailand
}

\begin{abstract}
Stumbling blocks to regional integration continue to pose a serious threat to the World Trade Organization (WTO), particularly during the COVID-19 pandemic. This study aims to examine the effect of regional economic integration on trade in COVID-19 products for Association of Southeast Asian Nations (ASEAN) countries using quarterly data for 2010-2020. A panel data model is estimated using the Poisson pseudo-maximum likelihood approach to address zero trade values, cross-sectional dependence, and heterogeneity problems. The findings of a case study on bilateral trade in COVID-19 products reveal that the ASEAN regional trade agreement is a stumbling block to the WTO's rules-based multilateral trading system. The results indicate that the home country's productive capacity, the host country's absorptive capacity, the countries' similarity in size and per capita income, and the countries' remoteness have positive and significant relationships with trade in COVID-19 products in ASEAN economies. This study provides several policy implications for Southeast Asian countries.
\end{abstract}

Keywords: Trade in COVID-19 goods, Regional economic integration, Building and stumbling blocks, Multilateral trading system, Association of Southeast Asian Nations

JEL Classifications: F11, F14, F15

Received 26 November 2020, Revised 19 January 2021, Accepted 4 February 2021

\section{Introduction}

Currently, trade access to COVID-19 goods is an immediate issue arising from the COVID-19 pandemic that no nation has avoided. The need for the medical products (i.e., medical equipment, supplies, medicines, and personal protective products, so-called COVID-19 goods) required to fight coronavirus disease has abruptly increased in countries worldwide. Trade measures related to COVID-19 goods, including both tariffs and non-tariff measures, such as export restrictions and barriers to imports of COVID-19 goods, which can include remoteness and cross-border mobility barriers, have broad impacts on many countries that rely on trade in COVID-19 goods. For WTO members, the most recent average applied most-favored nation (MFN) tariff for all medical products is $4.8 \%$ (WTO, 2020b), but this tariff is still higher than the preferential 
tariffs in regional trade agreements (RTAs). For instance, half of Association of Southeast Asian Nations (ASEAN) members have imposed applied MFN tariff rates that are above the world average, whereas all members have levied the preferential tariff rate, which is below the world average, in their RTAs. Additionally, ASEAN countries have imposed some non-tariff measures and barriers to COVID-19 products, such as temporary export bans on COVID-19 goods (by Cambodia, Malaysia, and Thailand), the temporary elimination of import license fees on related medicines (by Myanmar), the temporary relaxation of import licensing requirements for some protective products (by Singapore), and the elimination of export prohibitions and restrictions on essential goods, including expediting their movement through sea and air (also by Singapore) (WTO, 2020a).

Thus, RTAs are becoming increasingly important in the aftermath of COVID-19. RTAs are regional international treaties that apply only to their members and that aim to eliminate trade barriers and increase market access for their members. The share of world trade in medical goods accounted for by trade between ASEAN members increased from $1.4 \%$ in 2001 to $2.0 \%$ in 2019. The compound annual growth rate of ASEAN's trade in medical goods from 2001 to 2019 was $10.88 \%$, which was higher than the corresponding growth rate for non-ASEAN members of $8.93 \%$. Clearly, the COVID-19 pandemic impacted bilateral trade relations, and regionalization has further intensified (as Figure 1 shows). Interestingly, the trade effects (trade creation and diversion) of RTAs, which may cause either building or stumbling block effects on the road to the WTO's multilateral trading system, have not yet been determined.

Figure 1. Value of trade in medical goods (Million US\$), 2001-2019 (ITC, 2020)

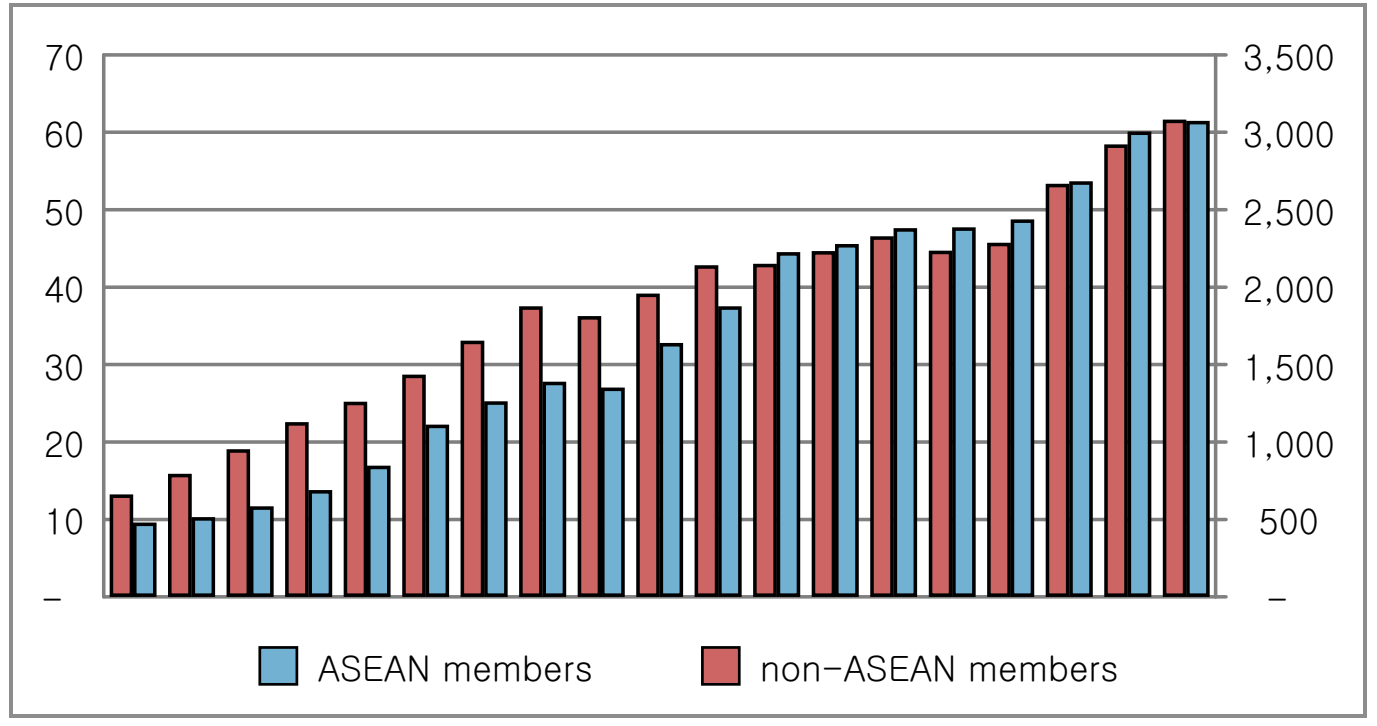

Thus, this study aims to estimate the influence of the ASEAN RTA on trade in COVID-19 
goods between six ASEAN economies and their 22 trading partners over the period 2010-2020 using a gravity model and a Poisson pseudo-maximum likelihood approach. We start by asking whether bilateral trade in COVID-19 goods is sensitive to intra-ASEAN trade relative to extra-ASEAN trade. International trade theory suggests that we should observe this sensitivity because an RTA (e.g., a free trade area focusing on the elimination of tariffs and non-tariff barriers) makes it easier for a country to access the foreign market and lowers trade costs (Anderson \& Wincoop, 2003; Bergstrand, 1985, 1989). We find that the ASEAN RTA positively impacts trade in COVID-19 goods and that its effect on intra-ASEAN trade flows is indeed larger than its effect on extra-ASEAN trade flows. Our findings also indicate whether this agreement is a building or stumbling block, as identified by Trotignon (2010), to fostering the WTO's multilateral trading system. Specifically, an increase in intra-ASEAN trade tends to enhance trade in COVID-19 goods but acts as a stumbling block to the WTO's multilateral trade liberalization.

This study is similar to those of Trotignon (2010), MacPhee and Sattayanuwat (2014), Nguyen (2019), and Jagdambe and Kannan (2020) owing to our focus on the effect of the ASEAN RTA on WTO membership. In fact, we follow these studies in defining the role of trade effects (trade creation and diversion) and considering the existence of building or stumbling blocks to the WTO's trading system. However, this study concentrates on trade in COVID-19 goods to better understand trade in the most necessary goods. It is one of the few studies investigating the impact of the ASEAN RTA in a COVID-19 trade context. This study also differs from existing studies in that we greatly emphasize RTA implementation by considering the values of intra-ASEAN trade, extra-ASEAN exports, and extra-ASEAN imports rather than simply focusing on the RTA's occurrence.

The remainder of this paper is organized as follows. Section II describes the empirical literature on the effects of RTAs. Section III outlines the estimation model and data collection. Section IV presents and discusses the empirical results. Section V concludes and describes the study's contributions.

\section{Theoretical Framework}

An extensive literature investigates the effects of RTAs. On one hand, many studies have examined the influence of RTAs on international trade. On the other hand, some studies have explored whether the realization of an RTA is a building or stumbling block to the WTO's multilateral trading system. We review the literature published from 2010 to 2020 regarding the effect of RTAs on trade flows with member and non-member countries and the impact on the global trading system. We formulate the conceptual framework of this study based on 
the following literature review.

\section{A. Effect of RTAs on trade}

The effects of RTAs on international trade have been subject to much debate. Recent empirical studies have provided strong results with as much rigor as possible. Bergstrand et al. (2015) examine the effects of economic integration agreements, international trade costs, and bilateral distance on trade flows in eight manufacturing sectors with 40 trading partners. Their findings on manufacturing trade flows, disaggregated manufacturing trade flows, and aggregate trade flows confirm that economic integration agreements have positive and significant impacts on trade flows. Baniya et al. (2020) explore the effects of trade time, tariffs, and preferential trade agreements (PTAs) on bilateral trade among Belt and Road Initiative (BRI) countries. They find that the time to trade based on geographical information system data and tariffs have negative and significant impacts on trade, whereas PTAs have positive and significant impacts on trade between BRI members. Le et al. (2020) investigate the impacts of a trade agreement (free trade area) and regional economic cooperation in the Greater Mekong sub-region (GMS) on Vietnam's exports to GMS partners. They find that the trade agreement positively and significantly impacts trade flows, whereas GMS economic cooperation negatively and significantly impacts trade flows. This finding reflects the importance of deeper economic integration to facilitating trade flows. Uzair and Nawaz (2020) analyze the impact of free trade agreements (i.e., the Pakistan-China free trade agreement, the Pakistan-Malaysia free trade agreement, and the Pakistan-Sri Lanka free trade agreement) on trade flows and find that only the Pakistan-China free trade agreement affects Pakistan's trade flows positively and significantly. Lee and Oh (2020) also examine the impact of a regional trading bloc (i.e., ASEAN) on export flows from ASEAN members to 29 trading partners and confirm that the relationship is positive and significant. Their findings are in line with those of Pant and Paul (2018) and Choi and Minondo (2019). Several recent studies estimate gravity trade models using stochastic frontier analysis to examine trade agreements' efficiency relative to maximum trade levels (Ravishankar \& Stack, 2014; Stack et al., 2018) and the long-run effects of trade flows (Anderson and Yotov, 2018; Devadason \& Mubarik, 2020). The empirical results of these two types of analyses suggest that the degree of trade agreements tends to improve trade flows' efficiency and dynamic trade flows.

H1: The formation of an RTA is likely to support bilateral trade in COVID-19 goods.

Moreover, many recent empirical studies address the extent to which the gravity trade variables impact bilateral trade. For instance, Khayat (2019) employs a gravity model to evaluate China's trade patterns with Organization of the Petroleum Exporting Countries members and 
finds, as expected, that gross domestic product (GDP) and population have significant positive impacts on trade flows, whereas distance has a significant negative effect on trade. His findings are in the line with those of Uzair and Nawaz (2020). Likewise, Le et al. (2020) reveal that trading countries' total GDP and GDP difference both have significant positive effects on trade flows, whereas per capita income has a significant negative impact on bilateral trade. Interestingly, a contiguous (inland) border between trading countries has a positive and significant relationship with bilateral trade. Jagdambe and Kannan (2020) show that the partner country's GDP and population impact agricultural trade flows positively and significantly, whereas the reporting country's population and distance have significant negative effects on trade. Their findings are similar to those of Jing et al. (2020), Leng et al. (2020), and Nasrullah et al. (2020).

H2: Gravity trade variables (i.e., economic size, market size similarity, and remoteness) tend to increase trade flows between countries.

\section{B. RTAs versus the global trading system}

Arguments that regionalism may be a building or a stumbling block to the WTO's multilateral trade liberalization have been widely developed in empirical studies by Baldwin and Seghezza (2010), Pfaffermayr (2020), and Trotignon (2010), among others. Baldwin and Seghezza (2010) examine the relationship between MFN and PTA tariffs and find that PTA tariffs have positive and significant effects on MFN tariffs. These results imply that trade agreements are a building block to global trade liberalization. Similarly, Mai and Stoyanov (2016) explore the relation between Canadian external tariffs and the Canada-US Free Trade Agreement provision and find that Canadian preferential tariffs impact MFN tariffs positively and significantly. The Canada-US Free Trade Agreement has a building block effect on Canada's multilateral tariff reductions. Their findings are in line with those of Ketterer et al. (2014). Pfaffermayr (2020) explores the effects of economic integration agreements (EIAs) on trade using a high-dimensional structural gravity panel model. His findings suggest that EIAs have trade creation effects, implying that they are a building block to the WTO trading system. Tabakis and Zanardi (2019) and Tovar (2019) investigate the effects of PTAs on the implementation of tariff and non-tariff measures. Tabakis and Zanardi (2019) show that PTAs reduce the utilization of anti-dumping measures against non-member countries. Tovar (2019) reveals that PTAs lower MFN tariffs and the use of temporary trade barriers, such as anti-dumping measures and safeguards, against both members and non-members. These findings confirm that PTAs are building blocks to the WTO trading system.

Moreover, to evaluate building and stumbling blocks, Trotignon (2010) defines the typology of trade creation and diversion and the implications of building and stumbling block effects. 
Intuitively, the formation of an RTA has trade effects on member and non-member countries. Trade is created among member countries, whereas trade with non-member countries may be created or diverted. Greater trade creation relative to trade diversion with non-member countries may be a building block to the WTO's trading system, whereas greater trade diversion relative to trade creation may be a stumbling block to multilateral trade liberalization. Trotignon (2010) then applies a gravity trade model with RTA dummies (i.e., intra-bloc trade, extra-bloc exports, and extra-bloc imports) to estimate the trade effects. His main results reveal that RTAs induce the creation of trade with both member and non-member countries, suggesting that RTAs support the WTO's multilateral trading system. Using the gravity trade model and the typology of trade effects suggested by Trotignon (2010), MacPhee and Sattayanuwat (2014), Khurana and Nauriyal (2017), Ngepah and Udeagha (2018), Nguyen (2019), Jagdambe and Kannan (2020), Freckleton and Whitely (2020), and Admassu (2020) also analyze the trade effects of selected RTAs. Their results on the trade effects of each RTA differ substantially, but they can still explain the building and stumbling block effects of the resulting trade creation and diversion. In addition, Bary (2015) uses the gravity trade model to examine the time-varying impact of an RTA (i.e., the ASEAN Free Trade Area, or AFTA) on trade flows. His results indicate that the AFTA created trade immediately but that this trade creation tended to decrease later on. These results imply that the AFTA was a building block to the WTO's trading system in the short run but a stumbling block in the long run. In addition, Libman (2020) confirms that the formation of the Eurasian Economic Union did not lessen its member countries' willingness to engage in WTO multilateral negotiations.

In sum, these studies suggest that RTAs have trade effects (e.g., trade creation and diversion effects) on member and non-member countries. The trade creation and diversion effects of RTAs create building or stumbling blocks to the WTO's rules-based multilateral trade liberalization (Trotignon, 2010).

\section{Econometric Approach}

\section{A. Model}

To investigate the effect of the formation of the AFTA on intra- and extra-ASEAN trade in COVID-19 goods, we rely on the gravity model of bilateral trade. The gravity model is widely used to explain bilateral trade between countries based on their economic sizes, geographical distance, and multilateral trade resistance. We estimate our empirical gravity equation based on the theoretical gravity model developed by Anderson and Wincoop (2003) and the empirical gravity model suggested by Trotignon (2010). Our gravity model is given 
by the following specification:

$$
\begin{aligned}
& \ln \left(e x p_{i j t}\right)=\beta_{0}+\beta_{1} \ln \left(g d p_{i t}\right)+\beta_{2} \ln \left(g d p_{j t}\right)+\beta_{3} \ln \left(s i m \_g d p_{i j t}\right)+ \\
& \beta_{4} \ln \left(\text { sim_gdppc }_{i j t}\right)+\beta_{5} \ln \left(\text { dist }_{i j}\right)+\beta_{6} \ln \left(\text { remote }_{i j t}\right)+ \\
& \propto_{1} \ln \left(i n t r a \_t r d_{t}\right)+\propto_{2} \ln \left(\text { extra_ex } p_{t}\right)+\propto_{3} \ln \left(\text { extra_imp } p_{t}\right)+\varepsilon_{i j t} \text {, }
\end{aligned}
$$

where $\exp _{i j t}$ is the value of COVID-19 goods exported from an ASEAN member $(i)$ to a trading partner $(j)$ over a given time period $(t) . g d p_{i t}$ and $g d p_{j t}$ are the GDPs of the given ASEAN member and trading partner for the given time period and serve as proxies for the economic sizes of countries $i$ and $j$. We utilize these variables to reflect the productive (supply) capacity of the exporting country and absorptive (demand) capacity of the importing country. sim_gdp $p_{i j t}$ is the similarity in the economic sizes (i.e., GDPs) of countries $i$ and $j$ and captures the similarities in trading partners' market potentials with ASEAN countries. It is calculated as $1-\left\{g d p_{i t} /\left(g d p_{i t}+g d p_{j t}\right)\right\}^{2}-\left\{g d p_{j t} /\left(g d p_{i t}+g d p_{j t}\right)\right\}^{2}$ (Helpman, 1987). sim_gdppc $c_{i j t}$ is the similarity in the per capita GDPs of countries $i$ and $j$ and is another measure of similarity in economic size. This variable is used to reflect the similarity in people's purchasing power in ASEAN and trading partner countries from an income per capita perspective, the difference in people's purchasing power, and vice versa. Generally, the signs of $\beta_{1}$ to $\beta_{4}$ are expected to be positive. dist $t_{i j}$ is the geographical distance between countries $i$ and $j$ and reflects the cost of trade with ASEAN and non-ASEAN members; the expected sign of $\beta_{5}$ is negative. remote $_{i j t}$ is the remoteness of countries $i$ and $j$ from the rest of the world, which represents multilateral trade resistance with the rest of the world. Remoteness is measured by multiplying the geographic distance between countries $i$ and $j$ by the share of country $j$ 's GDP in global GDP (Coe et al., 2007; Frankel \& Wei, 1998). Thus, the sign of $\beta_{6}$ should be positive. Moreover, three variables are employed to reflect the effects of the implementation of the ASEAN RTA: total intra-ASEAN trade, extra-ASEAN exports, and extra-ASEAN imports. intra_trd $t$ is the total value of intra-ASEAN trade in COVID-19 goods and represents the gain from trade in COVID-19 goods among ASEAN members, which we call intra-ASEAN trade creation. The sign of $\propto_{1}$ is expected to be positive. extra_exp $p_{t}$ is the total value of extra-ASEAN exports of COVID-19 goods and represents the effect of ASEAN members' interactions on the exports of ASEAN members to non-members in the region (i.e., expansion or contraction). The sign of $\propto_{2}$ may be positive and negative, reflecting extra-ASEAN export trade creation or diversion, respectively. extra_imp $p_{t}$ is the total value of extra-ASEAN imports of COVID-19 goods, representing the effect of ASEAN members' interactions on their imports from non-members in the region (i.e., expansion or contraction). The sign of $\propto_{3}$ may be positive or negative, 
reflecting extra-ASEAN import trade creation or diversion, respectively. Table 1 illustrates the typology of trade creation and diversion described by Trotignon (2010). $\varepsilon_{i j t}$ is an error term.

Table 1. Typology of Trade Creation and Diversion

\begin{tabular}{|c|c|c|}
\hline Acronym & Designation & Effects of regional trade agreement \\
\hline ITC & Intra-ASEAN trade creation & Stimulating effect on intra-ASEAN trade \\
\hline XTC & Extra-ASEAN export trade creation & Stimulating effect on extra-ASEAN exports to the rest of the world \\
\hline MTC & Extra-ASEAN import trade creation & Stimulating effect on extra-ASEAN imports to the rest of the world \\
\hline XTD & Extra-ASEAN export trade diversion & $\begin{array}{l}\text { Extra-ASEAN exports to the rest of the world are replaced by } \\
\text { intra-ASEAN trade }\end{array}$ \\
\hline MTD & Extra-ASEAN import trade diversion & $\begin{array}{l}\text { Extra-ASEAN imports from the rest of the world are replaced by } \\
\text { intra-ASEAN trade }\end{array}$ \\
\hline
\end{tabular}

(Source) Trotignon (2010), p. 241.

\section{B. Data sources}

We employ panel data for the regression analysis in this study. The data set includes bilateral quarterly observations covering six exporting ASEAN countries (i.e., Indonesia, Malaysia, Philippines, Singapore, Thailand, and Vietnam) and 51 importing countries in six regions (i.e., Africa, Southeast Asia, Asia-Pacific, Europe, North America, and Latin America), as illustrated in Table 2. In addition, our data cover the 39 quarters from the fourth quarter of 2010 to the second quarter of 2020 , giving a total of $6 \times 51 \times 39=11,934$ observations.

Table 2. Distribution of the Trading Partner Countries Used in This Study

\begin{tabular}{ll}
\hline Region & \multicolumn{1}{c}{ Countries } \\
\hline Africa & Nigeria \\
Southeast Asia & Indonesia, Malaysia, Philippines, Singapore, Thailand \\
Asia \& Pacific & Australia, China, India, Japan, Republic of Korea, Kyrgyzstan \\
Europe & Armenia, Austria, Belgium, Bulgaria, Croatia, Cyprus, Czech Republic, Denmark, Finland, France, \\
& $\begin{array}{l}\text { Germany, Greece, Hungary, Iceland, Ireland, Israel, Italy, Latvia, Lithuania, Malta, Netherlands, } \\
\text { Norway, Poland, Portugal, Romania, Russian Federation, Serbia, Slovakia, Slovenia, Spain, Sweden, }\end{array}$ \\
& $\begin{array}{l}\text { Switzerland, Turkey, United Kingdom } \\
\text { North America }\end{array}$ \\
Latin America & Canada, United States of America \\
\hline
\end{tabular}

We obtain quarterly data on the values of exports and imports of COVID-19 goods between the ASEAN countries and their 51 trading partner countries, measured in millions of US dollars at the current price level, from the International Trade Centre's trade map. COVID-19 goods in this study refer to COVID-19 medical supplies based on Harmonized system classification by World Customs Organization and World Health Organization. They are classified into eight 
categories: COVID-19 vaccines, test kits/instruments and apparatus used in diagnostic testing, Protective garments and the like, Disinfectants and sterilization products, Oxygen therapy equipment and pulse oximeters, Other medical devices and equipment, Other medical consumables, Vehicles, and Other (WCO, 2020). These data are the dependent variable, that is, ASEAN's exports of COVID-19 goods $\left(e x p_{i j}\right)$, and they are utilized to assess the three independent variables, that is, intra-ASEAN trade in COVID-19 goods (intra_trd), extra-ASEAN exports of COVID-19 goods (extra_exp), and extra-ASEAN imports of COVID-19 goods $($ extra_imp). Quarterly data on nominal GDP, measured in millions of US dollars, are gathered from the CEIC Global Database. These data represent the economic sizes of ASEAN countries $\left(g d p_{i}\right)$ and their trading partners $\left(g d p_{j}\right)$ and are used to assess similarity in economic size $\left(\right.$ sim_ $\left.g d p_{i j}\right)$ as well. Annual population data (in millions) are used to calculate similarity in per capita income $\left(s_{i m \_} g d p p c_{i j}\right)$ and are also sourced from the CEIC Global Database. The geographic distance between countries is calculated based on the longitudes and latitudes of the capital cities of the exporting and importing countries and is measured in nautical miles. This measure is used to compute the distance and remoteness variables. Descriptive statistics of the logarithm transformations of all of the variables are shown in Table 3.

Table 3. Descriptive Statistics of the Gravity Model Variables

\begin{tabular}{|c|c|c|c|c|c|}
\hline Variable & & Mean & Std. dev. & Min & Max \\
\hline lexpij & Bilateral export & 7.03 & 3.19 & - & 14.09 \\
\hline lgdpi & GDP of home country & 11.99 & 0.93 & 10.89 & 14.51 \\
\hline $\operatorname{lgdpj}$ & GDP of host country & 11.40 & 1.75 & 6.98 & 15.51 \\
\hline 1 sim_gdpij & $\begin{array}{l}\text { Similarity in market size between home } \\
\text { and host country }\end{array}$ & -0.68 & 1.31 & -6.13 & 0.68 \\
\hline lsim_gdppcij & $\begin{array}{l}\text { Similarity in income per capita between } \\
\text { home and host country }\end{array}$ & -0.05 & 0.80 & -3.95 & 0.67 \\
\hline ldistij & Distance between home and host country & 8.14 & 1.79 & -9.88 & 9.27 \\
\hline Iremoteij & $\begin{array}{l}\text { Remoteness between home and host } \\
\text { country from the rest of the world }\end{array}$ & 7.43 & 2.46 & -10.85 & 12.40 \\
\hline lintra_trd & Intra-ASEAN trade & 12.47 & 0.44 & 9.78 & 13.66 \\
\hline lextra_exp & Extra-ASEAN export & 14.01 & 1.28 & - & 15.04 \\
\hline lextra_imp & Extra-ASEAN import & 13.43 & 2.29 & - & 15.15 \\
\hline
\end{tabular}

Note. All variables are logarithm transformed. The number of observations is 11,934.

(Source) Author's calculation.

\section{Estimators}

The panel dataset used for this study consists of 306 bilateral pairs of countries and 39 quarter-years, which is a large amount of cross-sectional and time-series data. The panel-data 
gravity model that is typically applied to detect casual links in cross-sectional time-series data tends to encounter problems with panel errors, cross-sectional dependence, and zero trade values in the data. To avoid biased panel data estimation results, we first conduct diagnostic tests to confirm the existence of multicollinearity, heteroskedasticity, and serial correlation among the variables. This study primarily employs the Poisson pseudo-maximum likelihood (PPML) estimator suggested by Santos Silva and Tenreyro (2006) to investigate the effects of trade in COVID-19 goods in ASEAN member countries. We choose the PPML estimator because it can correct for zero trade values, heteroskedasticity, heterogeneity (from a large amount of cross-sectional data), and bias from log-normal disturbance terms in the model (Beck \& Katz, 1995; Santos Silva \& Tenreyro, 2006). In addition, we employ alternative estimators, such as the feasible generalized least squares model, Driscoll and Kraay (1998) standard errors for the coefficients, Newey-West standard errors for the coefficients, the panel-corrected standard error approach, and a fixed effect model as robustness checks.

\section{Estimation and Results}

\section{A. Is regionalism sensitive to trade in COVID-19 goods?}

Table 4 exhibits the results of the model diagnostic tests and of estimating the gravity equation (1) for bilateral trade in COVID-19 goods from six ASEAN countries to their 51 trading partners. We use six models: Model (1) captures ASEAN's bilateral trade with all trading partners, and Models (2) to (6) capture bilateral trade with trading partners in the Asia-Pacific, Latin America, North America, Europe, and Africa regions.

We start by conducting diagnostic tests of the models. The variance inflation factor (VIF) in Models (1) to (6) indicates that the models have no severe multicollinearity problems. The Pesaran tests for Models (1) to (6) conclude that Models (1), (2), (5), and (6) are likely to exhibit substantial cross-sectional dependence in the errors. The modified Wald tests indicate heteroskedasticity problems in Models (1) to (6). The Wooldridge tests for Models (1) to (6) find serial autocorrelation problems in almost all of the models. Hence, we primarily use the PPML approach to estimate the models.

In Model (1), all of the independent variables have statistically significant effects, implying that our chosen variables affect bilateral trade and that the gravity model approach is appropriate for explaining ASEAN's trade patterns. The estimated coefficients of the economic size variables (i.e., GDP, market size similarity, and per capita income similarity) are positive and significant. We find that $1 \%$ increases in the GDPs of ASEAN countries and their trading partners are associated with increases in bilateral trade in COVID-19 goods of approximately $0.19 \%$ and 
$0.05 \%$, respectively. GDP represents a country's level of productive capacity and absorptive capacity. Countries with high production capacities tend to specialize in and export more COVID-19 goods, whereas countries with high consumption capacities are likely to import more COVID-19 goods. These findings are in line with our hypothesis and support Jagdambe and Kannan's (2020) argument that higher GDPs in exporting countries are associated with greater production and availability of goods for trade, whereas higher GDPs in trading partners are related to greater purchasing power. We also find that $1 \%$ increases in the similarities of GDP and GDP per capita between ASEAN countries and their trading partners are likely to increase bilateral trade in COVID-19 goods by approximately $0.20 \%$ and $0.01 \%$, respectively. In line with our hypothesis, these results suggest that similarities in GDP and GDP per capita tend to increase the intra-industry trade between countries, whereas inter-industry trade is greater

Table 4. Effect of Regional Integration on Exports of COVID-19 Products Using the PPML Approach

\begin{tabular}{|c|c|c|c|c|c|c|}
\hline lexpij & $\begin{array}{l}\text { All } \\
(1)\end{array}$ & $\begin{array}{c}\text { Asia Pacific } \\
\text { (2) }\end{array}$ & $\begin{array}{c}\text { Latin America } \\
\text { (3) }\end{array}$ & $\begin{array}{c}\text { North America } \\
\text { (4) }\end{array}$ & $\begin{array}{c}\text { Europe } \\
(5)\end{array}$ & $\begin{array}{l}\text { Africa } \\
(6)\end{array}$ \\
\hline lgdpi & $\begin{array}{l}0.194 * \\
(39.50)\end{array}$ & $\begin{array}{l}0.171^{*} \\
(18.09)\end{array}$ & $\begin{array}{l}-0.008 \\
(-0.51)\end{array}$ & $\begin{array}{l}0.001 \\
(0.34)\end{array}$ & $\begin{array}{l}0.226^{*} \\
(31.35)\end{array}$ & $\begin{array}{l}0.445^{*} \\
(8.14)\end{array}$ \\
\hline lgdpj & $\begin{array}{l}0.050^{*} \\
(9.31)\end{array}$ & & & & & $\begin{array}{l}-0.467 \\
(-1.07)\end{array}$ \\
\hline lsim_gdpij & $\begin{array}{l}0.200^{*} \\
(23.87)\end{array}$ & $\begin{array}{l}0.333^{*} \\
(12.21)\end{array}$ & $\begin{array}{c}-0.058 * * \\
(-1.99)\end{array}$ & $\begin{array}{c}-0.071^{*} \\
(-6.24)\end{array}$ & $\begin{array}{l}0.183 * \\
(14.73)\end{array}$ & \\
\hline lsim_gdppcij & $\begin{array}{l}0.012 * \\
(2.64)\end{array}$ & $\begin{array}{l}0.051^{*} \\
(7.37)\end{array}$ & $\begin{array}{l}0.013 \\
(1.13)\end{array}$ & $\begin{array}{l}-0.099 * \\
(-10.74)\end{array}$ & $\begin{array}{l}0.024^{*} \\
(3.37)\end{array}$ & $\begin{array}{c}0.173 * \\
(5.94)\end{array}$ \\
\hline lremoteij & $\begin{array}{l}0.034^{*} \\
(8.91)\end{array}$ & $\begin{array}{l}0.038^{*} \\
(3.79)\end{array}$ & $\begin{array}{l}0.148^{*} \\
(10.27)\end{array}$ & $\begin{array}{l}0.119^{*} \\
(41.47)\end{array}$ & $\begin{array}{l}0.095^{*} \\
(14.25)\end{array}$ & $\begin{array}{l}0.580 \\
(1.55)\end{array}$ \\
\hline lintra_trd & $\begin{array}{l}0.389^{*} \\
(40.12)\end{array}$ & $\begin{array}{l}0.273^{*} \\
(17.84)\end{array}$ & $\begin{array}{l}0.479 * \\
(17.84)\end{array}$ & $\begin{array}{l}0.174 * \\
(28.98)\end{array}$ & $\begin{array}{l}0.449^{*} \\
(33.67)\end{array}$ & $\begin{array}{l}1.551^{*} \\
(10.96)\end{array}$ \\
\hline lextra_exp & $\begin{array}{l}-0.055^{*} \\
(-3.78)\end{array}$ & $\begin{array}{l}0.024 \\
(0.39)\end{array}$ & $\begin{array}{l}-0.007 \\
(-0.15)\end{array}$ & $\begin{array}{l}0.021 \\
(1.18)\end{array}$ & $\begin{array}{r}-0.332 * \\
(-7.39)\end{array}$ & $\begin{array}{l}0.393^{*} \\
(10.92)\end{array}$ \\
\hline lextra_imp & $\begin{array}{l}0.054^{*} \\
(8.10)\end{array}$ & $\begin{array}{l}-0.042 \\
(-0.62)\end{array}$ & $\begin{array}{l}0.0004 \\
(0.05)\end{array}$ & $\begin{array}{l}-0.014 \\
(-0.66)\end{array}$ & $\begin{array}{l}0.401 * \\
(6.21)\end{array}$ & $\begin{array}{l}0.015^{*} \\
(0.35)\end{array}$ \\
\hline Constant & $\begin{array}{l}-5.967 * \\
(-35.65)\end{array}$ & $\begin{array}{l}-3.401 * \\
(-8.77)\end{array}$ & $\begin{array}{c}-5.179^{*} \\
(-7.30)\end{array}$ & $\begin{array}{r}-1.205^{*} \\
(-7.29)\end{array}$ & $\begin{array}{l}-7.905^{*} \\
(-23.51)\end{array}$ & $\begin{array}{c}-25.724 * \\
(-8.31)\end{array}$ \\
\hline Observations & 11,934 & 1,404 & 702 & 468 & 7,956 & 234 \\
\hline R-square & 0.608 & 0.803 & 0.609 & 0.899 & 0.622 & 0.622 \\
\hline Psedo Log-Likelihood & -26977 & -3086 & -1444 & -990 & -17245 & -445 \\
\hline \multicolumn{7}{|l|}{ Diagnostic tests: } \\
\hline Pesaran's test & $76.48^{*}$ & $12.01^{*}$ & 1.00 & 0.80 & $99.74 *$ & -1.19 \\
\hline Wald test & $63000^{*}$ & $44025 *$ & $4588^{*}$ & $1385^{*}$ & $16240^{*}$ & $46.88^{*}$ \\
\hline Wooldridge test & $43.38^{*}$ & $14.99^{*}$ & $19.34^{*}$ & $15.51^{*}$ & $23.27^{*}$ & 2.84 \\
\hline VIF & 5.41 & 5.80 & 4.87 & 2.46 & 7.59 & 2.74 \\
\hline
\end{tabular}

Note. t-statistics are in parentheses; * significant with $p<0.01 ; * *$ significant with $p<0.05 ; * * *$ significant with $p<0.1$. (Source) Author's calculation. 
between countries with different GDPs and GDPs per capita. This evidence contrasts with Le et al.'s (2020) finding that a greater difference in countries' economic sizes leads to increased export and import flows.

The coefficient of remoteness, which reflects trade resistance, is positive and significant, suggesting that remoteness from the rest of the world increases bilateral trade in COVID-19 goods between ASEAN members and their trading partners by approximately $0.03 \%$. Greater remoteness from the rest of the world reflects greater proximity, better connectivity, and lower trade or transaction costs between trading countries, which may cause their trade flows to increase. These findings are in line with our hypothesis and are very similar to the findings of Jagdambe and Kannan (2020), Uzair and Nawaz (2020), and Le et al. (2020). They show that geographical proximity tends to enhance trade flows between countries because it reduces trade costs.

The coefficients of intra-ASEAN trade and extra-ASEAN imports are positive and significant, whereas the coefficient of extra-ASEAN exports is negative and significant. These findings suggest that $1 \%$ increases in intra-ASEAN trade and extra-ASEAN imports are likely to increase bilateral trade in COVID-19 goods by approximately $0.38 \%$ and $0.05 \%$, respectively. Given the ASEAN trade agreement, trade in COVID-19 goods is influenced by the expansion of trade with ASEAN members and growth in imports from non-ASEAN countries. However, a $1 \%$ increase in extra-ASEAN exports tends to diminish bilateral trade in COVID-19 goods by approximately $0.05 \%$, and trade in COVID-19 goods is associated with a contraction of exports to non-ASEAN countries. The positive impact of intra-ASEAN trade on trade flows reflects member countries' ability to stimulate their trade interconnectedness, whereas the positive relation between extra-ASEAN trade and trade flows reflects the trade opportunities of external relations with non-members. These results support the conclusions of Trotignon (2010) and Admassu (2020) that RTAs promote multilateral trade liberalization. However, they contradict the findings of Khurana and Nauriyal (2017) and Freckleton and Whitely (2020) that RTAs create trade diversion and may have a stumbling block effect on multilateral trade liberalization.

In Models (2) to (6), most of the estimated coefficients of the RTA variables are statistically significant, implying that forming an RTA is associated with intra- and extra-ASEAN trade expansion and contraction. The results of Models (3) and (5) are very similar to those of Model (1). The coefficients of the intra-ASEAN trade and extra-ASEAN import variables are positive and significant, whereas the coefficient of extra-ASEAN exports is negative and significant. These results suggest that intra-ASEAN trade stimulates the expansion of COVID-19 trade between ASEAN members and countries in Latin America and Europe. Additionally, increases in extra-ASEAN exports to countries in Latin America and Europe reduce ASEAN's bilateral trade in COVID-19 goods with those countries, whereas increases in extra-ASEAN imports 
from those countries enhance such trade. In Models (2) and (4), the coefficients of intra-ASEAN trade and extra-ASEAN imports are positive and significant, whereas the coefficient of extra-ASEAN exports is negative and significant. These results suggest that growth in trade in COVID-19 goods with Latin America and North America is associated with expansions of intra-ASEAN trade and extra-ASEAN imports. Finally, in Model (6), the coefficients of intra-ASEAN trade and extra-ASEAN trade (i.e., exports and imports) are positive and significant. This result indicates that intra- and extra-ASEAN trade in COVID-19 goods tends to stimulate ASEAN's bilateral trade in COVID-19 goods with countries in Africa.

In summary, our estimations confirm that ASEAN regionalism and the RTA are sensitive to trade in COVID-19 goods and impact ASEAN's trade effects (i.e., trade creation and diversion). The more comprehensive effects of regionalism on the multilateral trading system (i.e., WTO membership) are presented in the next section.

\section{B. Regionalism and the WTO's trading system}

A crucial issue raised by the estimation results in the previous section is the impact of ASEAN regionalism and the RTA on the presence of building or stumbling blocks. To address this question, we use the coefficients of intra- and extra-ASEAN trade in COVID-19 goods obtained from Model (1) to determine the values of trade creation and diversion (i.e., the trade effects). There are four possible intra- and extra-ASEAN trade effects that may suggest the existence of building or stumbling blocks, as Table 5 shows.

Table 5. Trade Creation, Trade Diversion and Block Typology

\begin{tabular}{|c|c|c|c|c|c|}
\hline \multicolumn{3}{|c|}{ Expected sign of coefficients } & \multirow{2}{*}{$\begin{array}{l}\text { Difference in } \\
\text { absolute } \\
\text { coefficients }\end{array}$} & \multirow{2}{*}{$\begin{array}{l}\text { Trade creation or } \\
\text { diversion }\end{array}$} & \multirow[b]{2}{*}{ Building or Stumbling Block } \\
\hline $\begin{array}{c}\alpha_{1} \\
\text { intra_trd }\end{array}$ & $\begin{array}{c}\alpha_{2} \\
\text { extra_exp }\end{array}$ & $\begin{array}{c}\alpha_{3} \\
\text { extra_imp }\end{array}$ & & & \\
\hline+ & + & + & & ITC, XTC, MTC & Building block \\
\hline+ & + & - & $\begin{array}{l}\alpha_{1}>\left|\alpha_{3}\right| \\
\alpha_{1}<\left|\alpha_{3}\right|\end{array}$ & $\begin{array}{l}\text { ITC, XTC, MTD } \\
\text { XTC, MTD }\end{array}$ & $\begin{array}{l}\text { Building block if } \alpha_{2}>\left|\alpha_{3}\right| \text { or } \\
\text { Stumbling block if } \alpha_{2}<\left|\alpha_{3}\right|\end{array}$ \\
\hline+ & - & + & $\begin{array}{l}\alpha_{1}>\left|\alpha_{2}\right| \\
\alpha_{1}<\left|\alpha_{2}\right|\end{array}$ & $\begin{array}{l}\text { ITC, XTD, MTC } \\
\text { XTD, MTC }\end{array}$ & $\begin{array}{l}\text { Building block if } \alpha_{3}>\left|\alpha_{2}\right| \text { or } \\
\text { Stumbling block if } \alpha_{3}<\left|\alpha_{2}\right|\end{array}$ \\
\hline+ & - & - & $\begin{array}{l}\alpha_{1}>\left|\alpha_{2}+\alpha_{3}\right| \\
\alpha_{1}<\left|\alpha_{2}+\alpha_{3}\right|\end{array}$ & $\begin{array}{l}\text { ITC, XTD, MTD } \\
\text { XTD and/or MTD }\end{array}$ & Stumbling block \\
\hline
\end{tabular}

(Source) Trotignon (2010), p. 242

The results in Table 6 show that the ASEAN RTA has a building block effect on the WTO's multilateral trading system. In Model (1), the ASEAN RTA tends to cause intra-ASEAN trade creation and extra-ASEAN trade diversion in COVID-19 goods (XTD>MTC). Hence, ASEAN's bilateral trade in COVID-19 goods leads to hinder ASEAN members from entering the WTO's 
multilateral trading system. This result implies that the ASEAN RTA is not a constructive force against global free trade. This finding is in contrast to that of Trotignon (2010), who finds that the ASEAN RTA stimulated the creation of trade between member and non-member countries. Additionally, the trade effects in Model (2) and (3) are very similar to those in Model (1). Bilateral trade in COVID-19 goods between ASEAN members and countries in the Asia-Pacific and Latin America regions, however, creates a stumbling block or obstacle to multilateral trade liberalization. It is likely to support ASEAN members leaving the WTO. Conversely, in Model (4) to (6), the ASEAN RTA is likely to induce both intra- and extra-ASEAN trade creation in COVID-19 goods. Trade with North America, Europe, and Africa serves as a building block, keeping ASEAN members from leaving the WTO.

Table 6. Trade Effects and the Impacts of the RTA

\begin{tabular}{lcccccc}
\hline & & \multicolumn{2}{c}{ Expected sign of coefficients } & \multicolumn{2}{c}{ Trade creation or trade } \\
\cline { 3 - 5 } Model & Region & $\begin{array}{c}\alpha_{1} \\
\text { intra_trd }\end{array}$ & $\begin{array}{c}\alpha_{2} \\
\text { extra_exp }\end{array}$ & $\begin{array}{c}\alpha_{3} \\
\text { extra_imp }\end{array}$ & Building or Stumbling \\
Block
\end{tabular}

Note. ITC $=$ Intra-ASEAN trade creation, XTC $=$ Extra-ASEAN export trade creation, MTC $=$ Extra-ASEAN import trade creation, XTD $=$ Extra-ASEAN export trade diversion, MTD = Extra-ASEAN import trade diversion

\section{Robustness checks}

To account for the possibility of endogeneity problems in our model, we conduct robustness checks. Table 7 shows a series of estimated results of robustness checks for the effects of ASEAN's bilateral trade in COVID-19 goods. Columns (1) to (5) present the coefficients of the gravity variables from Model (1) in Table 3 estimated using five panel-data estimators: the feasible generalized least squares method (GLS), Driscoll and Kraay (1998) standard errors for the coefficients (SCC), Newey-West standard errors for the coefficients (NEWEY), the panel-corrected standard error approach (PCSE), and a fixed effect model (FE), respectively. The results in Columns (1) to (4) are similar to those of Model (1) in Table 3. Market size, remoteness, and the RTA are significant factors affecting ASEAN's bilateral trade in COVID-19 goods with other countries. Intra-ASEAN trade and extra-ASEAN imports stimulate trade in COVID-19 goods in ASEAN, whereas extra-ASEAN exports reduce trade in COVID-19 goods in ASEAN. The results in Column (5), however, are rather different from those of Model (1) in Table 3. The coefficients of the GDPs of trading countries and the similarity in per capita 
income are negative and significant. These results contradict this study's hypothesis.

Table 7. Effects of Regional Integration on Exports of COVID-19 Products

\begin{tabular}{|c|c|c|c|c|c|}
\hline lexpij & $\begin{array}{l}\text { GLS } \\
(1)\end{array}$ & $\begin{array}{c}\text { SCC } \\
(2)\end{array}$ & $\begin{array}{c}\text { NEWEY } \\
\text { (3) }\end{array}$ & $\begin{array}{l}\text { PCSE } \\
(4)\end{array}$ & $\begin{array}{l}\mathrm{FE} \\
(5)\end{array}$ \\
\hline lgdpi & $\begin{array}{l}0.695^{*} \\
(10.21)\end{array}$ & $\begin{array}{l}0.722^{*} \\
(11.25)\end{array}$ & $\begin{array}{l}0.722 * \\
(25.36)\end{array}$ & $\begin{array}{l}0.722^{*} \\
(12.87)\end{array}$ & $\begin{array}{l}-0.242 \\
(-1.07)\end{array}$ \\
\hline lgdpj & $\begin{array}{l}0.849^{*} \\
(18.74)\end{array}$ & $\begin{array}{l}0.837^{*} \\
(14.77)\end{array}$ & $\begin{array}{c}0.837 * \\
(26.84)\end{array}$ & $\begin{array}{c}0.837^{*} \\
(16.58)\end{array}$ & $\begin{array}{c}-0.654 * * \\
(-1.96)\end{array}$ \\
\hline lsim_gdpij & $\begin{array}{l}0.415^{*} \\
(6.96)\end{array}$ & $\begin{array}{l}0.433^{*} \\
(4.95)\end{array}$ & $\begin{array}{l}0.433^{*} \\
(9.59)\end{array}$ & $\begin{array}{c}0.433 * \\
(5.85)\end{array}$ & $\begin{array}{l}0.606^{*} \\
(2.59)\end{array}$ \\
\hline lsim_gdppcij & $\begin{array}{l}0.015 \\
(0.62)\end{array}$ & $\begin{array}{l}0.024 \\
(0.58)\end{array}$ & $\begin{array}{l}0.024 \\
(0.77)\end{array}$ & $\begin{array}{l}0.024 \\
(0.65)\end{array}$ & $\begin{array}{c}-1.704 * \\
(-6.94)\end{array}$ \\
\hline lremoteij & $\begin{array}{l}0.217^{*} \\
(29.97)\end{array}$ & $\begin{array}{l}0.220^{*} \\
(8.38)\end{array}$ & $\begin{array}{l}0.220^{*} \\
(11.31)\end{array}$ & $\begin{array}{c}0.220^{*} \\
(14.29)\end{array}$ & $\begin{array}{l}1.492 * \\
(5.46)\end{array}$ \\
\hline lintra_trd & $\begin{array}{l}2.463^{*} \\
(68.09)\end{array}$ & $\begin{array}{l}2.479^{*} \\
(35.39)\end{array}$ & $\begin{array}{l}2.479^{*} \\
(40.92)\end{array}$ & $\begin{array}{l}2.479^{*} \\
(38.80)\end{array}$ & $\begin{array}{l}2.076^{*} \\
(19.64)\end{array}$ \\
\hline lextra_exp & $\begin{array}{c}-0.268 * \\
(-8.31)\end{array}$ & $\begin{array}{l}-0.311 \\
(-1.14)\end{array}$ & $\begin{array}{c}-0.311 * \\
(-3.10)\end{array}$ & $\begin{array}{c}-0.311 * * \\
(-2.17)\end{array}$ & $\begin{array}{l}0.478^{*} \\
(18.44)\end{array}$ \\
\hline lextra_imp & $\begin{array}{l}0.323^{*} \\
(17.20)\end{array}$ & $\begin{array}{l}0.345^{*} \\
(3.04)\end{array}$ & $\begin{array}{l}0.345^{*} \\
(7.82)\end{array}$ & $\begin{array}{c}0.345^{*} \\
(4.61)\end{array}$ & $\begin{array}{l}-0.006 \\
(-0.17)\end{array}$ \\
\hline Constant & $\begin{array}{c}-43.645^{*} \\
(-64.39)\end{array}$ & $\begin{array}{c}-43.726^{*} \\
(-24.05)\end{array}$ & $\begin{array}{c}-43.726^{*} \\
(-43.18)\end{array}$ & $\begin{array}{c}-43.726^{*} \\
(4.61)\end{array}$ & $\begin{array}{c}-25.889^{*} \\
(-17.80)\end{array}$ \\
\hline Observations & 11,934 & 11,934 & 11,934 & 11,934 & 11,934 \\
\hline R-square & & 0.64 & & 0.64 & \\
\hline $\mathrm{F}$ test & $14415^{*}$ & $3958^{*}$ & $3810^{*}$ & $32564 *$ & $146.49 *$ \\
\hline Hausman test & & & & & $208.14 *$ \\
\hline
\end{tabular}

Note. $\mathrm{t}$-statistics are in parentheses; $*$ significant with $\mathrm{p}<0.01 ; * *$ significant with $\mathrm{p}<0.05 ; * * *$ significant with $\mathrm{p}<0.1$. (Source) Author's calculation.

\section{Concluding Remarks}

Although the COVID-19 pandemic has severely impacted the world economy, trade barriers in COVID-19 goods have created more stress for many countries that rely on these goods. RTAs are necessary to eliminate trade barriers in COVID-19 products to combat the pandemic. This study examined the effects of the ASEAN RTA on trade in COVID-19 goods in ASEAN countries and the effects of ASEAN membership on the WTO's multilateral trading system. We used quarterly data for six ASEAN countries and 51 trading partners for the years 2010 to 2020, and we apply a PPML estimator to investigate the effects of gravity trade variables and an RTA on trade in COVID-19 goods. The estimated results show that the gravity trade variables have highly significant effects with the expected signs. The empirical findings also 
suggest that intra-ASEAN trade is significantly positively correlated with trade in COVID-19 goods, implying the presence of trade creation with member countries. Extra-ASEAN imports have a positive and significant impact on trade in COVID-19 goods, suggesting the presence of trade creation between ASEAN members and non-ASEAN countries. However, extra-ASEAN exports have a negative and significant impact on trade in COVID-19 goods, implying that trade diversion against non-ASEAN members exists. Importantly, trade between ASEAN and non-ASEAN countries seems to be a particular stumbling block to the WTO's multilateral trading system. This study makes two contributions. First, it contributes to the literature by determining the effect of the ASEAN RTA on trade in COVID-19 products, which are necessary for combatting COVID-19. Second, unlike other studies, which define the RTA variable as the occurrence of an RTA, this study defines it based on the change in the total trade value before and after an RTA's establishment.

The important policy implications of this study relate to improving trade relations among ASEAN members and non-ASEAN countries. ASEAN should strongly consider forming region-to-region trade agreements, such as the bilateral trade agreement between ASEAN and five major trading partners (i.e., Australia, China, Japan, South Korea, and New Zealand) in the Asia-Pacific region signed in November 2020. In addition, the EU and ASEAN should establish a deeper relation through the EU-ASEAN free trade area, as suggested by Paderon (2020). We make this suggestion because trade in COVID-19 goods through the ASEAN RTA tends to improve trade creation with ASEAN members but may support or obstruct trade with non-ASEAN countries in the context of multilateral trade liberalization. ASEAN should particularly engage in region-to-region trade agreements in the Asia-Pacific and Latin America regions to mitigate stumbling blocks to the WTO trading system. Moreover, policymakers should consider solutions for stimulating trade creation with ASEAN and non-ASEAN countries and reducing trade diversion away from non-ASEAN members. Thus, the governments of ASEAN countries should try to eliminate important but not necessary trade measures for expanding market access in COVID-19 products, maximize the facilitation of trade in COVID-19 goods to efficiently improve the supply chain for these products, and determine the mutual benefits of trade between trading counties. To reduce trade diversion effects against non-ASEAN members, ASEAN governments should enact trade complementarity measures with non-ASEAN members so that trade with the rest of the world is not overly substituted by intra-ASEAN trade.

\section{References}

Admassu, S. (2020). The trade creation effects of Africa's reciprocal vis-à-vis non-reciprocal trade 
agreements. Empirical Economics, 59, 2717-2730. doi: 0.1007/s00181-019-01723-3

Anderson, J. E., \& Wincoop, E. V. (2003). Gravity with gravitas: A solution to the border puzzle. American Economic Review, 93(1), 170-192. doi: 10.1257/000282803321455214

Anderson, J. E., \& Yotov, Y. V. (2018). Short run gravity. Journal of International Economics. doi: 10.1016/j.jinteco.2020.103341

Baldwin, R., \& Seghezza, E. (2010). Are trade blocs building or stumbling blocs?. Journal of Economic Integration, 25(2), 276-297. doi: 10.11130/jei.2010.25.2.276

Baniya, S., Rocha, N., \& Ruta, M. (2020). Trade effects of the new Silk Road: A gravity analysis. Journal of Development Economics, 146, 102467. doi: 10.1016/j.jdeveco.2020.102467

Bary, P. (2015). The time-varying impact of regional trade agreement: Evidence from ASEAN. Asian Economic and Financial Review, 5(9), 1061-1075. doi: 10.18488/journal.aefr/2015.5.9/102.9.1061.1075

Beck, N., \& Katz, J. N. (1995). What to do (and not to do) with time-series cross-section data. The American Political Science Review, 89(3), 634-647. doi: 10.2307/2082979

Bergstrand, J. (1985). The gravity equation in international trade: Some microeconomics foundations and empirical evidence. Review of Economics and Statistics, 67, 474-481. doi: 10.2307/1925976

Bergstrand, J. (1989). The generalized gravity equation, monopolistic competition, and the factor-proportions theory in international trade. Review of Economics and Statistics, 71, 143-153. doi: 10.2307/1928061

Bergstrand, J. H., Larch, M., \& Yotov, Y. V. (2015). Economic integration agreements, border effects, and distance elasticities in the gravity equation. European Economic Review, 78, 307-327. doi: 10.1016/j.euroecorev.2015.06.003

Choi, J., \& Minondo, A. (2019). The trade effects of Albania's trade agreements with CEFTA members. Post-Communist Economies. doi: 10.1080/14631377.2018.1537736

Coe, D., Subramanian, A., \& Tamirisa, N. T. (2007). The missing globalization puzzle: Evidence of the declining importance of distance. IMF Staff Papers, 54(1), 34-58. doi: 10.1057/palgrave.imfsp.9450003

Devadason, E. S., \& Mubarik, S. (2020). ASEAN and the EU: An assessment of interregional trade potentials. International Economics and Economic Policy, 17, 705-726. doi: 10.1007/s10368-020-00471-5

Driscoll, J. C., \& Kraay, A. C. (1998). Consistent covariance matrix estimation with spatially dependent panel data. Review of Economics and Statistics, 80(4), 549-560. doi: 10.1162/003465398557825

Frankel, J., \& Wei, S-J. (1998). Regionalization of world trade and currencies: Economics and politics. In J. A. Frankel (Ed.), The regionalization of the world economy (pp. 189-226). Chicago, USA: University of Chicago Press.

Freckleton, M., \& Whitely, P. (2020). Can trade agreements among small countries create trade? International Journal of Development Issues, 19(2), 205-216. doi: 10.1108/IJDI-06-2019-0110

Helpman, E. (1987). Imperfect competition and international trade: Evidence from fourteen industrial countries. Journal of the Japanese and International Economies, 1(1), 62-81. doi: 10.1016/0889-1583(8 7) $90027-X$

International Trade Centre (ITC). (2020). Trade map. Geneva: Switzerland. Retrieved from https://www.tra demap.org/Index.aspx (accessed September 15, 2020).

Jagdambe, S., \& Kannan, E. (2020). Effects of ASEAN-India free trade agreement on agricultural trade: The gravity model approach. World Development Perspectives, 19, 100212. doi: 10.1016/j.wdp.2020.100212 
Jing, S., Zhihui, L., Jinhua, C., \& Zhiyao, S. (2020). China's renewable energy trade potential in the "Belt-and-Road" countries: A gravity model analysis. Renewable Energy, 161, 1025-1035. doi: 10.1016/j.renene.2020.06.134

Ketterer, T. D., Bernhofen, D., \& Milner, C. (2014). Preferences, rent destruction and multilateral liberalization: The building block effect of CUSFTA. Journal of International Economics, 92(1), 63-77. doi: 10.1016/j.jinteco.2013.10.011

Khayat, S. H. (2019). A gravity model analysis for trade between the GCC and developed countries. Cogent Economics \& Finance, 7(1), 1703440. doi: 10.1080/23322039.2019.1703440

Khurana, R., \& Nauriyal, D. K. (2017). ASEAN-India free trade agreement: Evaluating trade creation and trade diversion effects. Journal of East-West Business. doi: 10.1080/10669868.2017.1322548

Le, B. H., Nguyen, D. Q., Vu, K. T., \& Luu, H. N. (2020). Economic cooperation in the Greater Mekong sub-region. Journal of Economic Integration, 35(2), 240-263. doi: 10.11130/jei.2020.35.2.240

Lee, J. W., \& Oh, J. (2020). ASEAN or plus alpha? The effectiveness of regional economic cooperation. Asia Pacific Management Review, 25(1), 48-53. doi: 10.1016/j.apmrv.2019.07.001

Leng, A., Shuai, J., Sun, H., Shi, Z., \& Wang, Z. (2020). Do China's wind energy products have potentials for trade with the "Belt and Road" countries? -- A gravity model approach. Energy Policy, 137, 111172. doi: 10.1016/j.enpol.2019.111172

Libman, A. (2020). Eurasian regionalism and the WTO: A building block or a stumbling stone? Post-Communist Economies. doi: 10.1080/14631377.2020.1793589

MacPhee, C. R., \& Sattayanuwat, W. (2014). Consequence of regional trade agreements to developing countries. Journal of Economic Integration, 29(1), 64-94. doi: 10.11130/jei.2014.29.1.64

Mai, J., \& Stoyanov, A. (2016). The effect of the Canada-US free trade agreement on Canadian multilateral trade liberalization. Canadian Journal of Economics, 48(3), 1067-1098. doi: 10.1111/caje.12168

Nasrullah, M., Chang, L., Khan, K., Rizwanullah, M., Zulfiqar, F., \& Ishfaq, M. (2020). Determinants of forest product group trade by gravity model approach: A case study of China. Forest Policy and Economics, 113, 102117. doi: 10.1016/j.forpol.2020.102117

Ngepah, N., \& Udeagha, M. C. (2018). African regional trade agreements and intra-African trade. Journal of Economic Integration, 33(1), 1176-1199. doi: 10.11130/jei.2018.33.1.1176

Nguyen, D. B. (2019). A new examination of the impacts of regional trade agreements on international trade patterns. Journal of Economic Integration, 34(2), 236-279. doi: 10.11130/jei.2019.34.2.236

Paderon, M. M. A. (2020). Opportunities in ASEAN-EU economic cooperation. International Economics and Economic Policy, 17, 783-798. doi: 10.1007/s10368-020-00473-3

Pant, M., \& Paul, A. (2018). The role of regional trade agreements: In the case of India. Journal of Economic Integration, 33(3), 538-571. doi: 10.11130/jei.2018.33.3.538

Pfaffermayr, M. (2020). Trade creation and trade diversion of economic integration agreements revisited: A constrained panel pseudo-maximum likelihood approach. Review of World Economics, 156(4), 985-1024. doi: 10.1007/s10290-020-00389-9

Ravishankar, G., \& Stack, M. M. (2014). The gravity model and trade efficiency: A stochastic frontier analysis of Eastern European countries' potential trade. The World Economy, 37(5), 690-704. doi: $10.1111 /$ twec. 12144 
Santos Silva, J. M. C., \& Tenreyro, S. (2006). The log of gravity. The Review of Economics and Statistics, 88(4), 641-658. doi: 10.1162/rest.88.4.641

Stack, M. M., Pentecost, E. J., \& Ravishankar, G. (2018). A stochastic frontier analysis of trade efficiency for the new EU member states: Implications of Brexit. Economic Issues, 23(1), 35-53.

Tabakis, C., \& Zanardi, M. (2019). Preferential trade agreements and antidumping protection. Journal of International Economics, 121, 103246. doi: 10.1016/j.jinteco.2019.07.001

Tovar, P. (2019). Preferential and multilateral liberalization: Evidence from Latin America's use of tariffs, antidumping and safeguards. Journal of Development Economics, 141, 102383. doi: 10.1016/j.jdeveco. 2019.102383

Trotignon, J. (2010). Does regional integration promote the multilateralization of trade flows? A gravity model using panel data. Journal of Economic Integration, 25(2), 223-251. doi: 10.11130/jei.2010.25.2.223

Uzair, L., \& Nawaz, A. (2020). The epoch of free trade agreements in Pakistan and predominance of China. The Chinese Economy, 53(5), 395-411. doi: 10.1080/10971475.2020.1730563

World Customs Organization (WCO). (2020). HS classification reference for COVID-19 medical supplies 3.01 Edition. Brussels: Belgium. Retrieved from http://www.wcoomd.org/-/media/wco/public/global/pd f/topics/nomenclature/covid_19/hs-classification-reference_edition-3_en.pdf?la=en (accessed February 20, 2021).

World Trade Organization (WTO). (2020a). COVID-19 and world trade. Geneva: Switzerland. Retrieved from https://www.wto.org/english/tratop_e/covid19_e/covid19_e.htm (accessed November 23, 2020).

World Trade Organization (WTO). (2020b). The WTO data portal. Geneva: Switzerland. Retrieved from https://timeseries.wto.org/ (accessed November 23, 2020). 